\title{
Tomasz Marcysiak
}

\section{Zapis wywiadu narracyjnego jako przyczynek do badań autoetnograficznych wsi kosznajderskich}

Swoją pracę poświęcam ludziom i losom tych, którzy z różnych powodów chcieli lub musieli opuścić swoje domy i przenieść się w inne miejsce w trakcie i po zakończeniu drugiej wojny światowej, ale i tym, którzy urodzili się i mieszkali całe życie na ziemiach, które często zmieniały swoich gospodarzy. Od 2010 r. przemierzam wsie, w których spotykam prawdziwe, żywe skarby kultury, czyli ludzi z ich często zawiłą, czasem dramatyczną, ale jakże i barwną historią. Ważne jest więc podtrzymywanie nie tylko pamięci historycznej zapisanej na kartach podręczników i prac naukowych, ale i pamięci doświadczonej, przeżytej, która nieustannie kształtuje zbiorową tożsamość. Tożsamość miejsca i ludzi, którzy mogą powiedzieć ,jestem stąd i jestem z tego dumny”. Za miejsce badań wybrałem początkowo powiat tucholski, ale z czasem obszar badań zaczął się znacznie poszerzać z powodu Atlantydy Borów Tucholskich, czyli Kosznajderii. Niniejszy artykuł jest jedynie fragmentem obszernego projektu badawczego, którego rdzeniem jest tożsamość społeczności postmigracyjnych i autochtonicznych na Ziemiach Odzyskanych. Ilustracją do opowieści o Kosznajderii jest w tym wypadku jeden bohater Bernard Gliszczyński (ur. 1933) lub jak widnieje na pamiątce z pierwszej komunii świętej z 27 sierpnia 1944 r. Bernhard Mrosek von Glischinski.

Słowa kluczowe: Kosznajderia, autoetnografia, socjologia wsi, badania jakościowe.

\section{Wprowadzenie}

Badanie świata społecznego niewielkich społeczności, małych wsi i osad, a nawet całych regionów etnograficznych jest nie tylko zajęciem pasjonującym, ale i obowiązkiem, spłaceniem długu zaciągniętego w poprzednich pokoleniach, które bez siły współczesnych mediów tworzyły krajobraz kulturowy polskiej wsi. Dziś w formie interdyscyplinarnych projektów łączy się praktykę i wiedzę historyków regionów, etnografów, socjologów wsi, czy geografów społecznych, aby nie tylko przybliżyć szerszym odbiorcom społeczno-historycznego kontekst naszej kultury i dziedzictwa, ale i zachować w pamięci zanikające tradycje, obyczaje, zwyczaje, obrzędy, język i wszystko to, co decydowało niegdyś o lokalnym mikroładzie społecznym pozwalającym przetrwać pokoleniom, zachowując w pamięci historię swoich przodków. Historię, z której mogą być dumni 
i która stale ulega reinterpretacji, tak jak zmianie podlegają nasze wspomnienia. Chodzi jednak nie tylko o naukowe i systematyczne uporządkowanie definicji, typów, kategorii i zmiennych, ale także o zachęcenie ludzi niezajmujących się na co dzień praktyką badawczą, aby w swych lokalnych środowiskach podejmowali próby budowania tożsamości lokalnej opartej na pamięci doświadczonej i przeżytej współczesnych mieszkańców wsi. Dlatego też w moich opracowaniach staram się przybliżyć do stylu Stanisława Rychlińskiego. Uważam jego język i namiętność publicystyczną stosowaną w przekazie naukowym za bardzo dobrą cechę, która ujawnia wyniki badań naukowych nie tylko akademickiej publiczności. Jak sam pisze w ostatnim rozdziale Lustracji:

Ogłaszane drukiem wyniki powinny mieć charakter dokumentacji reportażowej, z całą jej lekkością i dynamiką ujęcia oraz z umiejętnym zastosowaniem chwytów syntetyzujących [...]. Wszelka sztuczna poza naukowości jest szkodliwa - rzecz musi być dostępna dla każdego o wykształceniu szkoły powszechnej (Rychliński 2001, s. 102).

Za najważniejsze przesłanie Rychlińskiego uważam też postulat przyjęcia uczącej postawy badawczej, niemal zawsze świeżej wobec nowego celu i problemu badawczego, ale i elastycznej, w której badacz ze względu na specyfikę środowiska, w którym przyszło mu prowadzić wywiady, będzie zmuszony do gromadzenia materiału empirycznego w długim okresie. Dotyczy to np. społeczności, które są nieufne wobec obcych i każdego badacza traktują jak intruza, nawet nie starając się znaleźć różnic między nim a akwizytorem dywanów ${ }^{1}$. Dlatego też staram się nie tyle wygładzać wypowiedzi moich rozmówców, co nadawać im pewien kształt publicystyczno-reporterskiego wywodu. Sądzę zatem, że jeśli nie stosuje się jednoznacznie zasady wiernej transkrypcji wywiadu, to można (tak jak w tym przypadku) odstąpić od zasady zamykania każdej wypowiedzi w cudzysłowie, a czytelnik doskonale zorientuje się, kiedy w wypowiedź rozmówcy ingerował stylistycznie autor badań. Tym bardziej, że kilkugodzinne wywiady narracyjne najczęściej składają się z fleszy, chwilowych błysków wspomnień, wielokrotnych powrotów do tych samych wydarzeń i urywanych w połowie retrospekcji. Uporządkowanie tych myśli to również często nie lada wyzwanie. Czytelnik może odnieść wrażenie, że w tekście przenikają się przekazy mówiącego i słuchającego. To celowy zabieg, którego celem było ogłoszenie fragmentu wyników badań w formie publicystyczno-reporterskiej, co można zaliczyć do wyróżników autoetnografii ewokatywnej. Jak wyjaśnia Anna Kacperczyk, ,akt zapisu tego, czego się doświadczyło, przybiera postać spójnej

1 „Zawsze badaczowi terenowemu groziło, że mógł być poczytany za wywiadowcę urzędu skarbowego lub władz administracyjnych” (Rychliński 2001, s. 42). 
opowieści" (Kacperczyk 2014, s. 47). Przychylam się przy tym do postulatu Stanisława Andreskiego, by wypowiadać się w pierwszej osobie, gdyż ,ja”, jak uważa autor książki Czarnoksięstwo $w$ naukach społecznych, to ,śmiertelna i omylna jednostka, mająca prawo do wyrażania swojej opinii”' (Andreski 2002, s. 198). Bliższy jest mi zatem styl komunikacji z czytelnikiem Anthony'ego Giddensa, który, rozwijając swoją myśl na temat zasad metody socjologicznej, stosuje zwroty ,skoncentruję się, zajmę się, [...] sformułowałem” itd. (Giddens 2001, s. 136-137).

\section{Miejsce, metoda badań i kontekst historyczny}

Powiat tucholski składa się z sześciu gmin: gminy miejsko-wiejskiej Tuchola oraz gmin wiejskich: Cekcyn, Gostycyn, Kęsowo, Lubiewo i Śliwice. Pierwotny plan był taki, by kolejno w podobny sposób badać sąsiadujące ze sobą gminy wiejskie. Niespodziewanie trafiłem na region, o którym nie miałem pojęcia, ale może dlatego, że do niedawna nie był wpisany w regiony etnograficzne Polski. Mowa tu o obszarze położonym w trójkącie trzech miejscowości: Tucholi, Kamienia Krajeńskiego i Chojnic. Przez wieki region ten nazywany Kosznajderią zamieszkiwany był przez przesiedloną z Niemiec społeczność rolniczą (Rink 1930). Z czasem społeczność ta zyskała odrębny, choć może i stygmatyzujący ją status. Dla Polaków zawsze byli zbyt niemieccy, a dla Niemców byli zbyt polscy. Miało mieć na to wpływ m.in. to, że byli katolikami, a w okresie zaborów i polityki Kulturkampfu, kultywując obrzędy katolickie, byli bliżej tradycji polskiej niż niemieckiej. Dlatego też po zakończeniu 123-letniego okresu zaborów i odzyskania przez Polskę niepodległości, mimo że ich ziemie przyłączono do II Rzeczypospolitej, pozostali, uważając, że i tak są u siebie.

Sytuacja ta miała się jednak diametralnie zmienić z końcem drugiej wojny światowej. Niemcy z tego terenu albo uciekli w głąb Rzeszy, albo rozproszyli się po okolicznych miejscowościach (było przecież wiele mieszanych małżeństw i rodzinnych koligacji), albo zginęli z rąk czerwonoarmistów. Skala migracji była wówczas ogromna. Jednak w liczbach bezwzględnych w najwyższym stopniu przesiedleniami została dotknięta ludność niemiecka. Głównie z obawy przed Sowietami i za sprawą rozkazów władz nazistowskich uciekło 7,5 mln Niemców (Dorow 2010, s. 16). Faktem jest, że po 1945 r. ziemie te znalazły nowych mieszkańców, którzy, jak się okazuje, nie byli początkowo wcale tacy pewni tego, że znaleźli tu nowe miejsce do życia i że pewnego dnia nie wrócą po swoje dawni mieszkańcy. Jak się organizowali, skąd migrowali, kim byli i co pamiętają? 


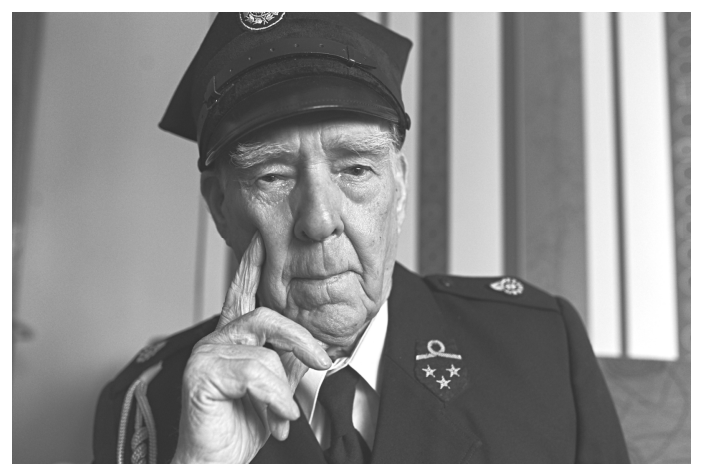

Ryc. 1. Bernard Gliszczyński

Źródło: fot. D. Bareya (2016)

To wszystko stało się moim nowym naukowym wyzwaniem, które przyniosło nie tylko interesujące rezultaty, ale także całkowicie nowe wątki poszukiwań przerwanej tożsamości społeczności postemigracyjnej. W swoich badaniach przyjąłem postawę autoetnograficzną, czyli opartą na specyficznej metodzie otrzymywania danych i docieraniu do informacji, która wpisuje się w nurt badań jakościowych w naukach społecznych. Kacperczyk wyróżnia trzy poziomy, na których wykorzystywana jest autoetnografia: poziom wytwarzania danych, poziom rozwiązywania problemów badawczych i poziom epistemologiczny (Kacperczyk 2014, s. 32). Na tym etapie moich badań autoetnografia pozostaje techniką otrzymywania informacji, a więc na poziomie pierwszym. Prowadząc badania nad tożsamością społeczności postmigracyjnych kierowałem się w pierwszej kolejności nasyceniem reprezentacją rozmówców typowych kategorii członków społeczności postmigracyjnych, takich jak: autochtoni, spolonizowani Niemcy, migranci przymusowi z Kresów Wschodnich, migranci ekonomiczni z centralnej Polski (radomskie, kieleckie) i weteranów wojennych, którzy wracając $\mathrm{z}$ frontu, zajmowali poniemieckie domy w pasie granicznym wzdłuż Odry i Nysy Łużyckiej. W artykule przybliżam wspomnienie Bernarda Gliszczyńskiego (ryc. 1), który reprezentuje polskich autochtonów z terenów samego centrum Kosznajderii.

\section{Ziemie Odzyskane i wielka migracja}

W pierwszych latach po zakończeniu drugiej wojny światowej Europa Środkowo-Wschodnia stała się areną wielkich wędrówek przesiedlonych i wypędzonych. Przymusowa migracja dotknęła niemal 10\% społeczeństwa polskiego i 20\% społeczeństwa niemieckiego (Jałowiecki, Szczepański 2007). 
Poniemieckie ziemie przyznane Polsce podczas konferencji w Poczdamie ${ }^{2}$ stanowiły trzecią część terytorium państwa polskiego w nowych granicach. Posiadały dla Polski dużą wartość ze względów ekonomicznych, a również politycznych, wojskowych i społecznych. Były też częściowym zrównoważeniem straty 46 procent przedwojennego obszaru państwa polskiego na rzecz ZSRR (Osękowski 2017).

Dla niemal 8,5 mln osób był to czas albo trudnych decyzji, albo braku wyboru. Połowa z nich zdecydowała o ucieczce na Zachód. Dla jednych była to przymusowa ewakuacja, dla innych ucieczka przed czerwonoarmistami. Tak czy inaczej większość opuściła swoje domy, by już nigdy do nich nie powrócić. Mimo to ok. 2,5 mln Niemców zostało na Śląsku, $1 \mathrm{mln}$ na Pomorzu Zachodnim, 550 tys. w Prusach Wschodnich, 350 tys. na Ziemi Lubuskiej i 200 tys. na terenie byłego Wolnego Miasta Gdańska (Osękowski 2017). Jak wyjaśnia dalej C. Osękowski (2017), po przejściu frontu część osób powróciła do dawnych miejsc zamieszkania, co sprawiło, że w niektórych wsiach liczba Niemców wzrosła, ale już nigdy nie zbliżyła do przedwojennego stanu. W regionach, które od lat były przygraniczne i wymieszane narodowościowo a które zostały po stronie polskiej, nastąpił czas weryfikacji „niebudzących wątpliwości”, kto jest kim. Inaczej mówiąc, kto jest Niemcem, a kto Polakiem.

Jedna $\mathrm{z}$ wielu interesujących mnie wsi to dawna stolica nieistniejącego już regionu historycznego Kosznajderii - Ostrowite. Wieś jest położona w okolicach Chojnic, a jej historia sięga czasów, kiedy to o jej nazwie decydowali Niemcy, a wcześniej nawet Krzyżacy (Szwankowski 2013). Tak jak przed wiekami, tak i dziś mieszkańcy Ostrowitego zajmują się głównie rolnictwem i hodowlą zwierząt gospodarskich. W pewnym sensie historię Kosznajderii zamyka 1945 r. i koniec wojny. Z tej wsi większość mieszkańców także była zmuszona uciekać przed radzieckim frontem. Po wojnie zostało jeszcze kilkoro mieszkańców, ale już chyba i po nich ślad dziś zaginął. Dla w pełni zaludnionej przez Polaków wsi Ostrowite otworzyły się nowe, niezapisane jeszcze karty historii. Na szczęście żyją jednak do dziś ludzie (choć już nieliczni), którzy pamiętają czasy okupacji, pamiętają tych, których nazywano Kosznajdrami, i pamiętają zmiany, jakie na ich oczach dokonywały się wraz z zasiedlaniem tych ziem przez nowych osadników, głównie rodzin z okolic Kielc i Radomia. Jednym z nich jest Pan Bernard, mieszkaniec Nowego Ostrowitego.

${ }^{2}$ Konferencja poczdamska (17 lipca1945 r. - 2 sierpnia1945 r. w Poczdamie w pałacu Cecilienhof) - spotkanie przywódców koalicji antyhitlerowskiej, tzw. wielkiej trójki. 


\section{Ich bin Kusznajder}

Pan Bernard swą opowieść zaczyna od sprostowania, że to nie byli Kosznajdrzy, jak o nich wspomniałem, tylko Kusznajdrzy. Do dziś pamiętam - wyjaśnia Pan Bernard - jak moi niemieccy rówieśnicy ze szkoły mówili o sobie „Ich bin Kusznajder". Dodaje też własną wersję pochodzenia nazwy Kosznajderii, wyjaśniając przy tym, dlaczego to powinna być Kusznajderia. Jak oni tutaj nastali dawno, dawno temu, to przez pomyłkę zamiast byka zarżnęli krowę ${ }^{3}$, stąd i ich nazwa Kuhsnajder. Są i tacy, uzupełnia mój rozmówca, którzy uważają, że nazwa regionu pochodzi od nazwiska Koszyński. Tu gdzie ja mieszkam (Nowe Ostrowite) była granica, a centrum Kosznajderii było w Ostrowitem. Ślady osadnictwa tego regionu sięgają jednak ponad 2000 lat. Pan Bernard wspomina, że gdzieś za górką w Nowym Ostrowitem znaleziono groby kamienne, czworokątne z kamieniem na wierzchu. Były to oczywiście groby skrzynkowe, typowe dla okresu wczesnej epoki żelaza. Do takich grobów wkładano urny z prochami, które ozdabiane były na szyjce urny symbolem w kształcie twarzy, stąd też nazwa - urny twarzowe ${ }^{4}$. Te znalezione w Nowym Ostrowitem zostały jednak zniszczone podczas melioracji, a było ich ponad dwadzieścia. Groby te zaorano razem z sadzawką zaraz po wojnie wraz z rozbudową PGR. Ci co kopali (uważa Pan Bernard), widzieli, że pod kołami są czworokąty z kamienia i urny z prochami, które mogli też wziąć za zwykłe garnki. Trudno dziś powiedzieć, czy ktokolwiek z archeologów badał to miejsce. Podobny grób znaleziono w Przymuszewie, jednak tam wydobycie urn odbyło się pod pełną kontrolą badaczy z UMK w Toruniu. Kamienny grób, choć już bez urn, do tej pory jest ustawiony na okolicznym cmentarzu.

\section{Polacy w Kosznajderii}

Tu nie było żadnego Polaka gospodarza (relacjonuje Pan Bernard), ewentualnie polscy robotnicy. W każdej wiosce był tu kołodziej, szewc, krawiec, mleczarz. We wsi przy sklepie najczęściej też był hotel i stajnia dla koni. Było tak i w Ostrowitem, i w Lichnowach. Podczas wojny jako chłopcy (knopy) przyglądaliśmy się, jak przywożą tam piękne ogiery i klacze. Nie było tu wielu Polaków, bo Niemcy nic od Polaków nie kupowali, mówili ,jesteś Polakiem, handluj sobie gdzie chcesz, ale nie tutaj". Polak więc albo plajtował, albo sprzedawał sklep Niemcom. Po dawnych mieszkańcach, tych krótko po wojnie

\footnotetext{
${ }^{3}$ Krowa (niem. Kuh), zarżnąć (niem. schlachten) przyp. autora.

${ }^{4} \mathrm{https}$ ://opencaching.pl/viewcache.php?wp=OP8MZL (20.07.2017).
} 
już też nic nie zostało. Były tu przecież takie domy, dwa ośmioraki dla robotników, gdzie mieszkali Karpińscy, Adamczyk, Niesiołowska. To było jednak byle jakie, więc szybko się rozpadło. Nasz dom też był lichy, spalił się w trakcie wojny i długo czekaliśmy na nowy, który wybudowali dopiero po roku zimowania u Konopa.

\section{Początek wojny}

O szóstej rano jechał pociąg pancerny z Człuchowa. Potem pierwszego września 1939 r. pierwszy raz zobaczyłem tankietkę (motocykle) na gąsienicach. Wkrótce wszystkich wywieźli do Zamartego. Później już była bitwa pod Krojantami. Ciekawe natomiast jest to, że ci Niemcy z naszej wsi już mieli mundury. Nawet w Ogorzelinach G...ki też miał taki żółtawy mundur niemiecki. Witał się tak wzorowo z Niemcami wyciągniętą prawą ręką do przodu, że pamiętam to do dziś. A potem i tak go zabrali na front. Wkrótce już była cała wieś we flagach nazistowskich. W pobliskim Ciechocinie odbywały się natomiast szybkie szkolenia młodych chłopaków. Dostawali potem mundury i do wojska.

\section{Frida Gatz i gołe niemieckie pośladki}

Frida Gatz była tak podła, że nawet jej mąż się zastrzelił. Żaden Niemiec też jej nie lubił. Miała gospodarstwo ponad 280 morgów (1 morga pruska duża $=0,5673$ ha). Miała też 12 koni, ale zostały zabrane na wojnę. W zamian dostała woły. Ojciec mój pracował u tych Niemców całą okupację. Duże gospodarstwo w okolicy miał też niejaki Schreiber, a Schreibrów tu było wielu. Dlatego nazywano ich Pompel Schreiber, Zej Schreiber itp. Była też Schreiberka, miała sklep koło kościoła, tam gdzie teraz mieszka Baczyński. Ona jednak męża nie miała. Sklep miał też Zimmerman, nawet było tam kasyno z bilardem. Miał tam też salę i duży balkon na piętrze i pokoje hotelowe. Ja taki całe życie byłem, że jak mnie drzwiami wywalali, to właziłem oknem i tak właśnie było pewnego razu, jak mnie ojciec do tego sklepu kolonialnego wysłał po papierosy. Zawsze musiałem długo prosić tego Zimmermana o papierosy dla ojca, a ten się litował i dawał mi po dwie paczki. Bywało, że trzeba było się za nim nachodzić i naprosić, szukając po całym sklepie i na piętrach. I tak raz wlazłem na taką ich niemiecką zabawę. Goście najpierw grali w karty, a jak popili więcej piwka, wchodzili na stół, ściągali portki i wołali „Jezt wir tanzen tralala ...” i tańczyli na stole ... bez portek. Innych zabaw, obrzędów nie pamiętam. Nawet nie wiem, 
czy świętowali zakończenie żniw. Zawsze pracowałem od małego knopa. Frida, u której byliśmy parobkami, nic takiego, jak dożynki, chyba nie robiła, choć miała najlepiej wyposażone gospodarstwo. Miała wóz, bryczkę, maszynę do młócenia ośmiocylindrową, snopowiązałkę i śrutownik. Nikt czegoś takiego nie miał, co najwyżej dwustronną Fellę ${ }^{5}$ do koni. Mój brat też kosił od rana do wieczora. Przynosili nam tylko obiad. Jak skończyliśmy jedno, to zaczynało się drugie. Jesienią zbieraliśmy kartofle, a od koszenia aż krzyże pękały.

\section{Eingedeutsche - niemiecka lista narodowościowa}

Niemieckie dzieci nie pracowały wcale. Niemcy zawsze nas też bili, najczęściej po szkole. U Kosińskich były zaś cztery duże knopy (chłopaki). Zrobiliśmy raz taką akcję, że wieczorem zaczepiliśmy specjalnie ich dziewczyny (Niemców). Kosińscy schowali się w krzakach i jak znowu nas zaczepili, to nasze knopy im tak łby strzaskali, że się nas już nie czepiali. Skąd tu młodzi Polacy? Wszyscy mieliśmy podpisaną listę Eingedeutschte ${ }^{6}$. Nie było wyjścia, albo lista, albo śmierć. Ojciec i inni stali prawie do końca pod ścianą. Jak jednak zaczęli Niemcy odliczać do pięciu, to już gdy było trzy, wszyscy się ugięli i podpisali listę. Strach był tym większy, ponieważ co niektórzy dostali już wcześniej listy z informacją o rozstrzelaniu kogoś z rodziny. Mieliśmy podpisaną listę, ale kim byliśmy? Tacy Niemcy nie Niemcy. Baliśmy się więc, że nas i tak po wojnie rozstrzelają. Obawy te nie były bezpodstawne. Mimo że na terenach poniemieckich dużo było i ziemi, i domów, to niemało było też konfliktów, których przyczyną były trudności wynikające z koegzystencji różnych grup. W przejęciu kontroli nad ładem społecznym i gospodarczym w nowej sytuacji konkurowali ze sobą Niemcy, autochtoni (do których zaliczała się i rodzina Pana Bernarda), przesiedleńcy z Kresów i centralnej Polski, Ukraińcy wysiedleni podczas Akcji Wisła, repatrianci z Francji, Niemiec, Rumunii, Jugosławii, a nawet uczestnicy wojny domowej w Grecji. Grupy te dzieliła przepaść kulturowa, historyczna i cywilizacyjna. Na to wszystko nakładały się także różnice wyznania, bo w jednym miejscu mogli się spotkać katolicy, prawosławni, grekokatolicy, ewangelicy i wyznawcy judaizmu ${ }^{7}$. Nie zawsze też decydowała liczebność, a zdolności polityczne czy adaptacyjne.

\footnotetext{
${ }^{5}$ Chodzi tu o przedwojenne niemieckie maszyny rolnicze konne firmy Bayern Fella.

${ }^{6}$ Volkslista - niemiecka lista narodowościowa dzieląca ludność na cztery kategorie (Volksdeutscher, Deutschstämmige, Eingedeutschte, Rückgedeutschte). Eingedeutschte - osoby autochtoniczne, uważane przez Niemców za częściowo spolonizowane.

7 http://www.polityka.pl/pomocnikhistoryczny/1674782,1,jak-odbywalo-sie-przesiedle nie-ludnosci-polskiej.read (22.07.2017).
} 


\section{Gąsior ze stawu}

Dostało się nam też kiedyś za zaginionego gąsiora. Przesłuchanie w tej sprawie było jak na gestapo. Cięgle te same pytania: co było wczoraj na obiad i czy nam gęsina smakowała. Tak dostałem kijem, że ledwo przeżyłem. O zjedzenie gąsiora posądziła nas właśnie Frida. Na wiosnę, kiedy śniegi zeszły i mróz odpuścił, okazało się, że gąsior pływał martwy w stawie. Normalnie wpadł w przerębel i się utopił. Kiedy już wyszła na jaw prawda, nie usłyszeliśmy nic, tylko Frida powiedziała Schade! ${ }^{8}$, nic więcej, żadnego przepraszam. Ojciec już wtedy chciał ją zatłuc, ale była wojna, nic nie można było zrobić.

\section{Blondynek}

Ja z końcem wojny byłem postrzelony w głowę. Jak przez wioskę przeleciały pierwsze samoloty, to już było wiadomo, że wojna przechyla się na stronę Ruskich. Nie pomogło strzelanie z armat do samolotów, które właśnie tym bardziej bombardowały stanowiska ogniowe i celowały prawie w nas. Pewnego razu, z raną głowy dostałem się między niemieckich rannych żołnierzy. W tym samym czasie podstawiono pociąg, którym Niemcy mieli uciekać prawdopodobnie na były niemiecki statek pasażerski MS Wilhelm Gustloff. Mnie też chcieli na ten transport wrzucić, uznając pewnie, że blondynek, to będzie z niego jeszcze dobry Niemiec. Nie udało im się. Prawie wszyscy Niemcy stąd, z Ostrowitego, chyba właśnie na ten statek uciekli, został tylko Janowitz. Nikt nie przeżył, bo nikt z tamtych Niemców tu już nigdy nie zaglądał. Bhenke też został i pewnie jeszcze kilku. Nie mówię, że to prawda, ale dlaczego nikt tu z przodków nie zagląda? Reszta opuściła ten region w 1946 r. Był nawet taki moment, że po wojnie Niemcy i Polacy pomagali sobie na gospodarstwie. Jak jednak i tym kazano wyjechać, słyszałem, że odgrażali się, że jak jakieś drzewo tu zetną, to oni tu wrócą i na tych drzewach powieszą Polaków. Nie wrócili już nigdy. Tu gdzie mieszkam (Nowe Ostrowite) przyjeżdżali czasem wnukowie, pamiętam takiego Martina. Do samego Ostrowitego jednak już nikt nie zaglądał. Frida Gatz myślała, że będzie dalej tu gospodarować. Na Wybudowaniu ${ }^{9}$ nikt nikogo nie powiadomił, więc i kilku Niemców też zostało, m.in. tam, gdzie ten czerwony buk. Pozostałych załadowano na pociąg w Chojnicach. Ja z bratem załadowałem na wózek dobytek Niemców i jak wypakowaliśmy Niemców z ich

\footnotetext{
${ }^{8}$ Szkoda (niem.)

${ }^{9}$ Określenie dla domów wybudowanych z dala od wsi, ale posiadających jej nazwę $\mathrm{w}$ adresie pocztowym.
} 
wózków, to celowo nawet nie swoje i to całkiem nowe zabraliśmy ze sobą. Nie wszystko Niemcom udało się wywieść, a co zostało, to prawie wszystko zostawało szybko rozkradzione. Wyjątkiem były domy, które szybko zasiedlili nowi osadnicy. Dużo też szabrowali Ruskie lub szabrownicy, którzy z nimi szli. Takie na przykład Silno aż 18 razy przechodziło szaber albo niemiecki, albo ruski. Często też Ruskie brali nas za partyzantów, ale że znaliśmy w miarę dobrze ruski język, to zawsze udawało się ich przekonać, że te wózki to nasze, a my stąd. Z końcem wojny Ruskie najpierw byli u Fridy, szukali radiostacji. Rzekomo u Schreibra była radiostacja, ale tak naprawdę radiostacja była u Fridy. Sam widziałem, że miała takie wielkie nadawcze pudło. Ruskie natychmiast potłukli ją kolbami i szybko uciekli.

\section{Szkoła}

Przed wojną Niemcy szli do szkoły od siódmego roku życia (ryc. 2). Kiedy jednak wybuchła wojna, to i ja poszedłem do szkoły, mimo że miałem dopiero sześć lat.

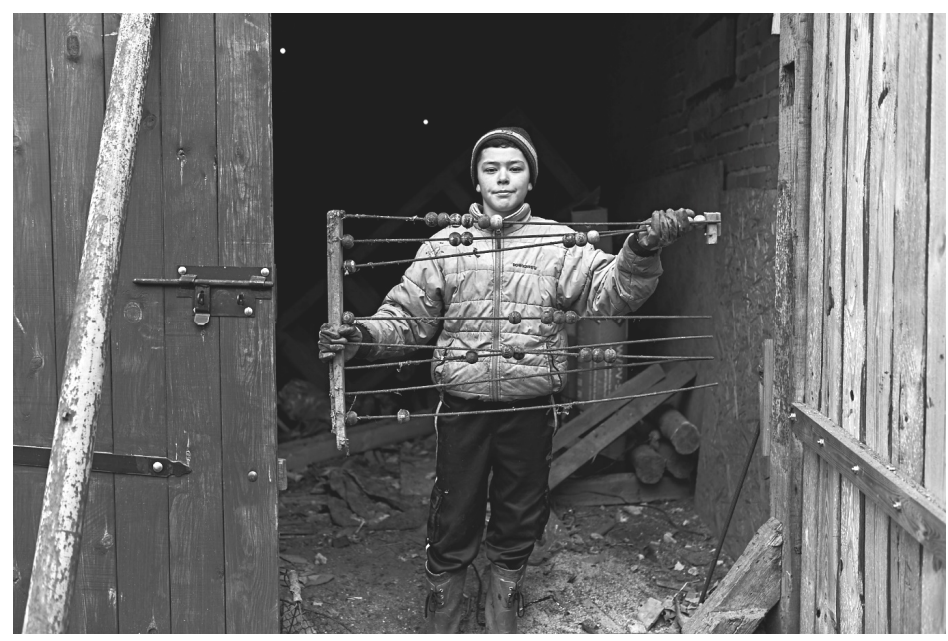

Ryc. 2. Chłopiec demonstrujący liczydło z przedwojennej szkoły Źródło: fot. D. Bareya (2016)

Ze mną też poszła moja starsza siostra. Przed wojną była klasa polska, nawet Niemcy się uczyli polskiego. W trakcie wojny już tylko uczono po niemiecku. Pamiętam nauczyciela, na którego mówiliśmy Igiel, bo miał włosy ścięte na jeża. Była też taka ładna nauczycielka, ale biła nas po rękach tak, że pręgi rosły. Paskudna „niemra” Niemców jednak też nie oszczędzała, więc i ją wysiudali. 


\section{Nowy dom, nowi sąsiedzi}

Po wojnie prawo osiedlania się $\mathrm{w}$ tym regionie w pierwszej kolejności mieli chyba ludzie z kieleckiego i łódzkiego, bo ich tu najwięcej. Każdy więc brał prawie, co chciał. Przez jakiś czas na gospodarstwach byli też Ruskie. Mieli krowy, rzeźnie, a mięso wysyłali na front lub do siebie. Byli tu dłużej niż rok. Dlatego nikt im tych gospodarstw nie zabierał. Ci więc co pracowali u Niemców na gospodarkach, które zajęli Ruskie, kiedy ci odeszli, przejmowali je. Smutne i trudne do zrozumienia dla nas, jako dzieci, było to, że jak przychodzili Polacy z centralnej Polski, z gotowym dokumentem, mówili do nas, jak do Niemców - Raus! wynocha, precz, teraz to nasze. Tak jak mówiłem wcześniej, byliśmy tacy Niemcy, ale nie Niemcy. Nie mając wyboru, wzięliśmy więc dom po Lenzu. Było tu też trochę ziemi, ale dom - to wszystko pod słomą, chyba najmniejszy w całej wsi. Był chlew, kuźnia, obora, no dom, jak mówiłem, pod strzechą, ale był.

\section{Ruskie we wsi}

W czasie okupacji ruskie chłopaki też pracowali w niemieckich gospodarstwach, jeden z nich pochodził nawet z Uralu. Gadaliśmy tu więc i po niemiecku, i po rusku. Był tu taki wielki chłopak z pokrzywionymi zębami. Robiliśmy sobie kawały. Raz temu Ruskiemu kazałem stanąć przy krowie, potem podniosłem jej ogon i krzyknąłem pstryk - masz zdjęcie. Ten skurczybyk jak mnie złapał, to tak mi naszczypał na tyłek, że pamiętam to dziś. Te Ruskie jak przyszli tu $\mathrm{w}$ niewolę, to wyglądali strasznie. Tak jak ich przyprowadzono, ubranych w powiązane łachy, w waciakch, to przez całą okupację tak chodzili. Sami zszywali te łachy, żeby im nie pospadały z pleców. Aż do momentu, kiedy wkroczyli Sałdaty. Natychmiast wyrzucili te rzeczy na gnojowiska i powyciągali z szaf garnitury. Ruskie żołnierze szybko znaleźli te ich lumpy i pytali, kto w takim czymś tu chodził? To mówiliśmy, że to ci niewolnicy, od was. Od razu chcieli za to tę Fridę zastrzelić. Frida zaś uciekła do nas i u nas z innymi Niemcami siedziała w piwnicy. Moja matka wiedziała, że ich zastrzelą, więc pozwoliła im się tu skryć. Wszyscy ryzykowaliśmy, bo i nas Ruskie uważali za Niemców. Dobrze, że najczęściej oficerowie byli pijani, może właśnie to ratowało nam czasem życie. Tu w ośmiorakach mieszkali też jeńcy angielscy. Mieli puszki, paczki z Anglii, takie hałdy, że można było to ciężarówką wywozić. W jednym pokoju to było ich ośmiu lub dziewięciu. Nawet miejscowe dziewczyny mieli. Obiecali im, że po wojnie przyjadą z papierami i się z nimi ożenią... Do tej pory żaden nie przyjechał. 


\section{Po wojnie}

Po wojnie wzięliśmy zalewisko, pierwsze gospodarstwo, tam gdzie dziś rzeźnik. Nikt tego nie chciał. Nie mieliśmy nawet koni. Chodziliśmy więc pożyczać albo konia, albo maszynę. W jednym gospodarstwie, które tymczasowo zajmowali Ruskie, mieli nawet traktor marki Deutz startujący z korby. Z braku paliwa takie silniki uruchamiano też na naftę lub alkohol. Ojciec potrafił uruchomić każdy silnik, ale nie zawsze się to opłacało. Pewnego razu uruchomił tego Deutza i jak tylko dumny wyjechał na drogę, Ruski poprosił, by mógł się przejechać. Tymczasem jak wsiadł, tak już z niego nie wysiadł i tyle go widzieliśmy.

W pierwszym roku po wojnie przyszła do nas nauczycielka (Rusałka) i utworzyła dwie klasy - pierwszą i czwartą. Kto umiał czytać szedł do czwartej, kto nie, to do pierwszej. Ja po polsku czytać nie umiałem, tylko po niemiecku. Troszkę znałem tylko litery. Zaglądałem jednak przez ramię na urywek, który czytał akurat ten, co czytać umiał. Szybko się zgłosiłem i zacząłem z pamięci ten sam fragment ,jadą sanki drogą ...” i tak stałem się uczniem czwartej klasy. Potem też mieliśmy angielski z nauczycielem, wojskowym Michałowskim. Ten mówił też po francusku. Skończyłem siódmą klasę z bardzo dobrym wynikiem. Wszyscy poszli się gdzieś dalej uczyć i ja też wysłałem swoje dokumenty do szkoły budowlanej do Torunia. Matka jednak martwiła się, kto za tę szkołę i internat będzie płacić, skoro u nas siedmioro dzieci i pieniędzy na nic nigdy nie było. Mój brat - powiedziała matka - był przed wojną szewcem i takie pieniądze zarabiał, ja cię też do szewca dam. Nie było jednak tak łatwo, najpierw musiało się zwolnić miejsce na praktykę czeladniczą. Pół roku czekałem aż mnie przyjmie na stancję. Szewc był jednak pijaczyna, „baba” też do niczego i ciągle byłem głodny. Po trzech miesiącach uciekłem, to było niemożliwe. Do szkoły zawodowej chodziłem jednak dalej, ale jej nie skończyłem. Tuż przed skończeniem nauki ojciec stracił dłoń w sieczkarni i musiałem wrócić do domu i do pracy za ojca $\mathrm{w}$ gospodarstwie. Tak zleciało mi kolejne pięć lat, aż zaczęto zakładać spółdzielnie. Tu gdzie mieszkałem była kuźnia, trochę więc tu klepałem i czasem chodziłem poduczyć się do kowala. W ramach organizowania spółdzielni zajęto naszą gospodarkę, a mnie chciano dać do kuźni. Bez zawodu nie było gdzie jednak uciekać, więc poszedłem do PGR-u, gdzie przyjęto mnie, ale ... też do kuźni, bo nie mieli kowala. W papiery i tak nikt nie zaglądał. Ważne, że umiałem czytać i pisać wśród tych wszystkich analfabetów. Młóciłem więc parówką, nikt poza mną i tak się na tym nie znał. Wkrótce dostałem młocarnię ze Stalowej Woli. W krzakach stał kolczak, Ursus. Pojechałem do Chojnic i sam naprawiłem ciągnik. Księgowa wypisała mi zlecenie i dostałem do pomocy fajnego, robotnego knopa. W dwójkę tym kolczakiem młóciliśmy i całkiem niezłe 
pieniądze zarabiałem. W 1956 r. byłem już wykwalifikowanym robotnikiem i poszedłem na kurs. Tam nauczyłem się spawania, toczenia, bromowania itd. Od rana do wieczora nauczyłem się wszystkiego po trochu, ale w sumie i tak jeździłem ciągnikiem. Zrobiłem prawo jazdy i zacząłem jeździć lublinem, starem, ożeniłem się, i tak już do końca. Nawet zapisałem się do partii i zostałem przewodniczącym Związku. Na egzekutywie powiatowej w Chojnicach awansowali mnie do egzekutywy wojewódzkiej. Dziś dumny jestem najbardziej z munduru strażaka, który zawsze zakładam z ogromnym szacunkiem (i tak właśnie się też stało, na naszą prośbę). Życie Pana Bernarda nie było łatwe, choć mało $\mathrm{w}$ tej opowieści było utyskiwania i narzekania. Pan Bernard przecież przeżył i pewnie jego losy i historia wiele razy przeplatały się z historią kogoś z czytelników tego tekstu.

\section{Zakończenie i dalsze perspektywy badań}

W prezentowanym sposobie prowadzenie badań niemal zawsze pierwszym etapem jest eksploracja, następnie introspekcja, czyli sięganie do wnętrza, empatia. Wiąże się to z koniecznością przyjęcia roli innego. Nie tylko więc najważniejszą metodą jest wywiad narracyjny, ale także wniknięcie w otoczenie, mentalny i rzeczywisty spacer po wsi i okolicy. Pracę dokumentują nie tylko wywiady, ale i fotografie zebrane zarówno od moich rozmówców, jak i wykonywane podczas badań przez Dariusza Bareyę. Łączenie tych wszystkich metod jakościowych czy włączanie często ad hoc w trakcie badań terenowych kolejnych - to właśnie zaleta, a może lepiej powiedzieć cecha badań autoetnograficznych. W klasyce polskiego kina w Rejsie pada takie zdanie „Nie mogę być jednocześnie twórcą i tworzywem". W badaniach autoetnograficznych jest dokładnie na odwrót, badacz jest i twórcą, i tworzywem, m.in. dlatego, że nigdy nie pozostaje neutralny. Jak zauważa Krzysztof Konecki „Neutralny badacz nie istnieje, zwykle jest on zanurzony w czasie i historii, a jego decyzje są kontekstualne i związane z określonym dyskursem naukowym, w który jest zaangażowany" (Konecki 2012, s. 13).

Moim zamierzeniem jest takie nasycenie informacji i danych (wywiadów), które mogłyby posłużyć do dekonstrukcji pojęć, takich jak np. ,sprawiedliwość dziejowa". Jak pisał F. Znaniecki (2001, s. 257-258),

pewne własności danych przedmiotów lub faktów są zależne od ludzkiego doświadczenia, gdyż zmieniają się zależne od tego, kto i kiedy je doświadcza. [...] Najistotniejszą, ogólną cechą przedmiotów i faktów, badanych przez humanistę, jest właśnie to, że są one czyjeś, czyli że istnieją w działaniu i doświadczeniu pewnych ludzi i posiadają te właściwości, które im owi działający i doświadczający ludzie nadają w czynnościach i doznaniach. 
Dla przykładu, przejęcie w 1945 r. południowych Prus Wschodnich uważane było przez wielu Polaków za swoistą sprawiedliwość dziejową (Sakson 1999, s. 260), m.in. dlatego, że panowało powszechne przekonanie, że ziemie te są odwiecznie polskie. Był to jednak propagandowy zabieg, którego fundamentem miało być stworzenie mitu powrotu do macierzy. Według J. Poniedziałka (2011, s. 225),

Podstawową strategią $\mathrm{w}$ konstruowaniu tego mitu było więc zanegowanie niemieckiej przeszłości i odtworzenie lub wytworzenie polskości. Można mówić o negatywnej stronie budowy tego mitu (np. niszczenie śladów niemieckiej kultury materialnej (ryc. 3) i duchowej, realizując tzw. odniemczanie), jak i pozytywnej (budowa polskiej historii i tradycji odnoszących się do tej ziemi). Celem tego projektu mitycznego było wyrobienie wśród ludności napływowej poczucia, że ziemia, na której przyszło im żyć, po prostu im się należy. Dodatkowo w micie „Ziemi Odzyskanej - odwiecznej polskości” nie było miejsca na historię i tradycję Kresów Wschodnich oraz ludności ukraińskojęzycznej.

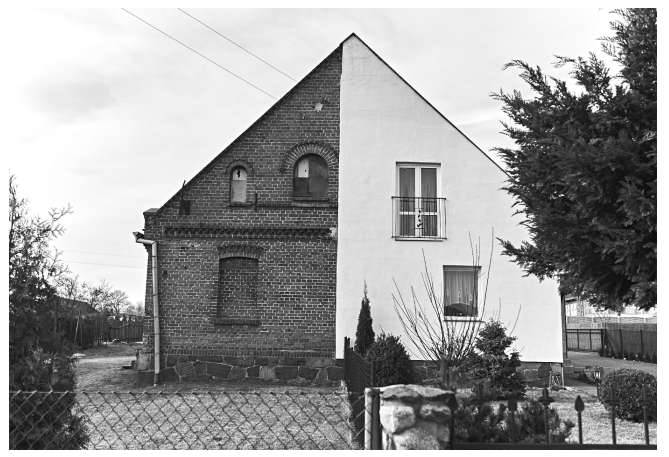

Ryc. 3. Znikająca architektura wsi kosznajderskich Źródło: fot. D. Bareya (2016)

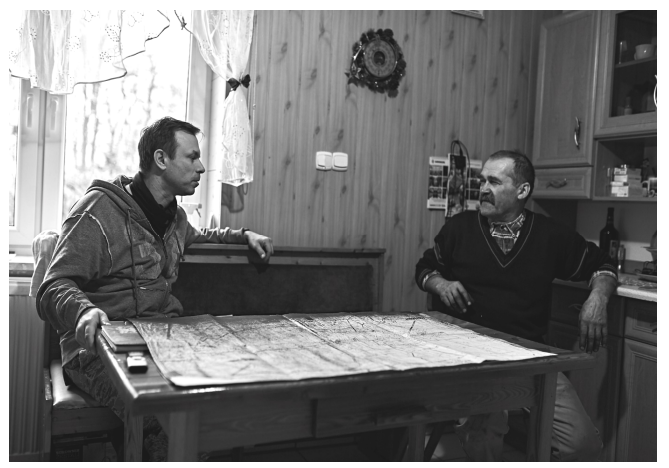

Ryc. 4. Przymuszewo - nowe wątki historii migrantów z Kresów (po lewej autor badań) Źródło: fot. D. Bareya (2016) 
Temat jest więc wciąż otwarty na nowe definicje sytuacji, choć niestety bezpośrednich świadków pewnych historycznych wydarzeń jest coraz mniej, ale nie zmniejsza to mojego naukowego zapału w dążeniu do odkrycia i spisania kolejnej historii, ważnej tak dla pojedynczego człowieka, jak i może (taką mam nadzieję) całej małej lokalnej wspólnoty (ryc. 4). To co jednak jest fascynujące w autoetnografii, to możliwość poznawania uczuć, myśli, które kryją się w sercach ludzi. To także przełamanie bariery zaufania, z którą wiąże się ryzyko ośmieszenia, obawy przed krytyką lub negatywnymi sankcjami nie tylko ze strony potencjalnych czytelników późniejszego opracowania, ale i sąsiadów, mieszkańców tej samej wsi. Często bowiem z treści i kontekstu autobiografii można się bez trudu domyślić „o kim mowa”. To już jednak leży w gestii poczucia etyki samego badawcza. Siła oddziaływania autoetnografii jest bardzo duża, o ile wraca do lokalnych społeczności i tylko w ich kontekście można ją analizować. To rodzaj autorefleksji, która ma sens tylko wtedy, jeśli jest osadzona w konkretnym kontekście kulturowym. Innymi słowy to pisanie autoetnografii jest nie tylko opowieścią, ale i narzędziem eksploracyjnym (Pelias 2015, s. 389).

\section{Literatura}

Andreski S., 2002, Czarnoksięstwo w naukach społecznych. Warszawa.

Dorow U., 2010, Zapomniana przeszłość. Upadek pomorskich majątków rolnych na przykładzie powiatu lęborskiego, Pruszcz Gdański.

Giddens A., 2001, Nowe zasady metody socjologicznej. Kraków.

Jałowiecki B., Szczepański M., 2007, Dziedzictwo polskich regionów, [w:] Kojder A. (red.), Jedna Polska? Dawne i nowe zróżnicowania społeczne, Wrocław.

Kacperczyk A., 2014, Autoetnografia - technika, metoda, nowy paradygmat? O metodologicznym statusie autoetnografii, „Przegląd Socjologii Jakościowej”, 10 (3), s. 32-74.

Konecki K.T., 2012, Wizualna teoria ugruntowana. Podstawowe zasady i procedury, „Przegląd Socjologii Jakościowej”, 8 (1), s. 12-45.

Osękowski C., 2017, Osadnictwo polskie na poniemieckich ziemiach po drugiej wojnie światowej. Ziemia Lubuska i powiat Gubin: http://www.transodra-online.net/pl/node /1411 (02.05.2017).

Pelias R.J., 2015, Writing autoethnography. The personal, poetic, and performative as compositional strategies, [w:] Jones S.H., Adams T.E., Ellis C., Handbook of autoethnography, Oxford, s. 384-405.

Poniedziałek J., 2011, Postmigracyjne tworzenie tożsamości regionalnej. Studium wspótczesnej warmińskomazurskości, Toruń.

Rink J., 1930, Vom Flach szum Leinen. Führer durch die Koschneider Spinn - und Webstube des Staatlichen Landesmuseums in Danzig-Olivia. 
Rychliński S., 2001, Lustracje społeczne, Warszawa.

Sakson A., 1999, Dylematy kształtowania się tożsamości regionalnej na Warmii i Mazurach, „Pogranicze. Studia Społeczne”, 8, s. 257-268.

Szwankowski J., (red.), 2013, Kosznajderia, Chojnice.

Znaniecki F., 2001, Socjologia wychowania, t. 2, Warszawa.

\section{A record of narrative interview as a contribution to autoethnographic research of the Koschneiderei villages}

\section{Summary}

I devote my work to the people and fate of those who for various reasons wanted or had to leave their homes and move to another place during and after the Second World War, but also to those who were born and lived their whole lives on the lands that often changed their landlords. Since 2010, I have been wandering through villages where I have met real, living treasures of culture, namely people, often with their intricate, sometimes dramatic, yet colourful histories. Therefore, it is important to maintain not only the historical memory written on the pages of textbooks and scientific papers, but also the experienced and endured memory, which constantly shapes the collective identity. The identity of place and people who can say "I am from here and I am proud of it". At the beginning of the research, I chose the Tuchola poviat, but over time, the research area began to considerably expand due to the Atlantis of the Tuchola Forest, i.e. the Koschneiderei. This article is only a fragment of an extensive research project whose core is the identity of post-migration and indigenous communities in the Recovered Territories. In this case, one hero - Bernard Gliszczyński (born in 1933) or, as it appears on the First Communion Favour of 27 August 1944 - Bernhard Mrosek von Glischinski, is an illustration of the story about the Koschneiderei.

Keywords: Koschneiderei, autoethnography, village sociology, qualitative research.

Tomasz Marcysiak, dr

Wyższa Szkoła Bankowa w Toruniu

ul. Młodzieżowa 31a, 87-100 Toruń

e-mail: tomasz.marcysiak@wsb.bydgoszcz.pl 